\title{
Dominance hierarchies in monkeys ${ }^{1,2}$
}

\author{
W. F. ANGERMEIER, JOHN B. PHELPS, M. ORESTE, AND HARRY DAVIS, FLORIDA PRESBYTERIAN COLLEGE
}

H. H. REYNOLDS, ARL, HOLLOMAN AFB, NEW MEXICO

Dominance tests were performed on 28-30 month-old male rhesus monkeys, reared from the age of 2 to 4 months under four different conditions of social and perceptual interaction. In tests which matched three Ss (each one from a different rearing and living condition), it was shown that the previously achieved dominance status was the most important and only significant factor which influences the formation of a new dominance hierarchy. When cagemates from one condition were matched with cagemates from the other condition, it was found that weight and the presence of a cagemate are significant determinants of the new dominance hierarchy. Cagemates always seem to act in concert.

In a previous study (Angermeier, Phelps, Murray, \& Reynolds, 1967) it was found that during the establishment of dominance, two monkeys from the same living condition, although they were not cage mates, always acted in concert when placed with a third animal from a different living condition. A notable exception to this rule was observed when two of the three animals came from a strict isolation environment, a living condition which prevented visual and tactual interaction among its members. Since only two tests were run under the latter condition, no definite trend in the interaction between the three animals was evident.

Two studies on rhesus monkeys are reported here. Study 1 was designed to explore the formation of a dominance hierarchy as it exists in three animals selected from three different rearing and living conditions. Study 2 investigated possible trends which would emerge when two well established dominance hierarchies were paired with one another.

\section{Subjects}

Male rhesus monkeys from a colony of 28 were used as Ss in this investigation. All the animals used here had previously participated in a matchto-sample discrimination study under a shock-escape paradigm. The animals were also used previously in dominance tests; however, none of them had ever been paired with any other of the present Ss. At the time of this study, all the animals were approximately 28-30 months of age. The animals came from four rearing and living conditions where they had been maintained since the age of 2-4 months. These four conditions were as follows: Enriched social (ES) -two animals per cage, play objects, swings, television, visual and some tactual interaction between cages; Social (S)-two animals per cage, visual and some tactual interaction between cages; Partial isolates (PI)-one animal per cage, visual and some tactual interaction between cages; Strict isolates (SI) -one animal per cage, no visual or tactual interaction between cages.

\section{Apparatus}

The testing apparatus was described in detail elsewhere (Angermeler, Phelps, Murray, \& Reynolds, 1967). Briefly, it consisted of a plastic cage, 34 in. wide, 48 in. high, and 72 in. long, with a grid floor, water fount, and perch. The cage was placed in a $9 \times 15 \mathrm{ft}$ room, with also contained a TV camera in one corner. Behind a large one way window in an adjacent room were a TV videotape system and a TV monitor. In this room there were also four observers who had the testing apparatus in full view through the one way window.

\section{Procedure}

In Study 1, three animals, each one from a different rearing environment, were placed into the testing apparatus. A total of six comparisons, involving 18 Ss, was made. In every test, the smallest animal was placed into the testing cage first, and the other two Ss followed within $60 \mathrm{sec}$. The criteria used to judge dominance have been described in detail elsewhere (Angermeier, Phelps, Murray, \& Reynolds, 1967), but included briefly: (1) sex-premounting and mounting; (2) aggression-hitting, biting, pushing, pull-

Table 1. Establishment of a Dominance Hierarchy

\begin{tabular}{|c|c|c|c|c|}
\hline Test Group $^{\mathrm{a}}$ & $\begin{array}{c}\text { Weights } \\
\text { in } \mathrm{oz}\end{array}$ & $\begin{array}{c}\text { Previous Dominance } \\
\text { Record } \\
\text { Won-Lost }\end{array}$ & $\begin{array}{c}\text { Rank } \\
\text { in this } \\
\text { Test }\end{array}$ & $\begin{array}{l}\text { Previous Dominance } \\
\text { Record Important }\end{array}$ \\
\hline ES & 152 & $2 \cdot 3$ & $1^{b}$ & \\
\hline SI & 154 & 1.4 & 2 & YES \\
\hline$S$ & 145 & $0-3$ & 3 & \\
\hline SI & 148 & $5-2$ & 1 & \\
\hline ES & 150 & $3-2$ & 2 & YES \\
\hline$S$ & 169 & 0.3 & 3 & \\
\hline PI & 216 & $3-0$ & 1 & \\
\hline ES & 216 & $2-3$ & 2 & YES \\
\hline SI & 209 & 0.3 & 3 & \\
\hline SI & 166 & 41 & 1 & \\
\hline$S$ & 207 & $2-2$ & 2 & YES \\
\hline PI & 161 & 1.4 & 3 & \\
\hline PI & 207 & $3-3$ & 1 & \\
\hline SI & 218 & $1-4$ & 2 & YES \\
\hline$S$ & 176 & $0-3$ & 3 & \\
\hline PI & 234 & $5-0$ & 1 & \\
\hline $\mathbf{S}$ & 184 & $2-3$ & 2 & YISS \\
\hline ES & 179 & $3-5$ & 3 & \\
\hline
\end{tabular}

${ }^{\mathrm{a}}$ Combination of animals from living condition and their weights were matched as closely as possible.

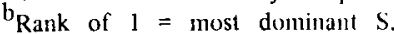


ing; and (3) position-preference, posture, and freedom of movement. The animals remained in the testing apparatus for a period of 15-30 min, until there was unanimous agreement among the four observers about the dominance hierarchy.

In Study 2, a pair of cage mates from one living condition ( $S$ ) was placed into the apparatus with a pair of cage mates from another living condition (ES). A total of six comparisons, involving $12 \mathrm{Ss}$, was made.

\section{Resulis and Discussion ${ }^{3}$}

The results of Study 1 appear in Table 1 . The data of Table 1 indicate that, without prior visual and tactual contact experience among the animals in a laboratory colony, previous dominance experience seemed to be the determining factor in the establishment of dominance which involved three animals, one each from three rearing and living conditions. A binomial test suggested by Siegel (1956) was applied to the number of times in which the previous dominance record was important in the establishment of an entirely new and different dominance hierarchy. The previous dominance factor was found to be significantly involved at the .001 level. Tests for the significant involvement of weight differentials and origin or living condition were not significant.

Even more interesting than the clear results which were obtained in this study was the way in which dominance was established between the three animals. In all six tests reported, the animal which turned out to be must dominant would turn its aggression (usually within $10 \mathrm{sec}$ ) against the animal ranking second. After the dominance fight between these two animals, the animal ranked 1 mounted the animal ranked 2, which in turn would attack the animal ranked 3 . This pattern was astonishingly similar in all six tests performed. In none of the six tests reported here did an animal ranked first ever interact in a significant fashion with an animal ranked third.

The study suggested that in the absence of any previous social interaction among nonhuman primates (rhesus monkeys), the formation of a new dominance hierarchy seems to depend upon a previously established dominance record.

The results of Study 2 appear in Table 2. The raw data presented in Table 2 were analyzed by the binomial test suggested by Siegel (1956). The importance of the cage mates for the outcome of the
Table 2. Pairing of Dominance Hierarchies in Monkeys

\begin{tabular}{lcccc}
\hline Test Group & $\begin{array}{c}\text { Weights } \\
\text { in oz }\end{array}$ & $\begin{array}{c}\text { Previous Dominance } \\
\text { Record } \\
\text { Won-Lost }\end{array}$ & $\begin{array}{c}\text { Rank } \\
\text { in this } \\
\text { test }\end{array}$ & $\begin{array}{c}\text { Cagemates \& Weights } \\
\text { Important }\end{array}$ \\
\hline ES $^{\text {a }}$ & 408 & $10-6$ & $1,2^{\text {b }}$ & YES \\
S & 314 & $0-10$ & 3,4 & \\
S & 391 & $6-7$ & 1,2 & YES \\
ES & 302 & $8-5$ & 3,4 & \\
S & 436 & $5-10$ & 1,2 & YES \\
ES & 368 & $4-9$ & 3,4 & \\
ES & 408 & $10-6$ & 1,2 & YES \\
S & 391 & $6-7$ & 3,4 & \\
ES & 368 & $4-9$ & 1,2 & YES \\
S & 314 & $0-10$ & 3,4 & \\
S & 436 & $5-10$ & 1,2 & YES \\
ES & 302 & $8-5$ & 3,4 & \\
\hline
\end{tabular}

${ }^{a}$ Each rearing condition consisted of two cagemates.

${ }^{b} l=$ most dominant

dominance tests was significant at the .016 level. The importance of the weight differential was also significant at the .016 level. The importance of the previous dominance record was found to be nonsignificant.

The data of Study 2 seem to warrant the following conclusions: (1) When well established dominance hierarchies are paired with each other, both weight and the presence of a cage mate are important factors; (2) cage mates always achieve dominance ranks of 1 and 2 or 3 and 4 when paired with other cage mates, from different living environments; and (3) the pairing of dominance hierarchies seems to result in a number of predictable behavior patterns.

\section{References}

ANGERMEIER, W. F., PHELPS, J. B., MURRAY, S., \& REYNOLDS, H. H. Dominance in monkeys: the influence of the laboratory home environment. Psychon. Sci., 1967, 9, 433-434.

SIEGEL, S. Nonparametric statistics. New York: McGraw-Hill, 1956.

\section{Notes}

1. This research was supported by AF Contracts AF29(600)-5135 and F29600-67-C-0011 between the Aeromedical Research Laboratory, Holloman AFB, New Mexico and Florida Presbyterian College.

2. A more detailed report is available upon request.

3. Blood biochemical determinations on the Ss used here were made and included: Cholinesterase, Calcium, Tyrosine, Cholesterol, Serum Total Protein, and SGOT. Little or no differences were found between the least and the most dominant rhesus monkeys in our colony. 